\title{
Jumping the water queue: changing waterscapes under water reform processes in rural Zimbabwe
}

\author{
JS Kemerink-Seyoum ${ }^{1,2 *}$, NLT Chinguno ${ }^{1 \dagger}$, SD Seyoum 1, R Ahlers ${ }^{3}$, JA Bolding ${ }^{4}$ and P van der Zaag ${ }^{1,5}$ \\ IIntegrated Water Systems and Governance department, UNESCO-IHE, PO Box 3015, 2601 DA Delft, the Netherlands \\ ${ }^{2}$ Governance and Inclusive Development, Department of Geography, University of Amsterdam, PO Box 19268, 1000 GG, Amsterdam, The Netherlands \\ 3 Independent Researcher, Frederik Hendrikstraat 113C, 1052HN Amsterdam, the Netherlands \\ ${ }^{4}$ Water Resources Management Group, Wageningen University, PO Box 47, 6700AA, Wageningen, The Netherlands \\ ${ }^{5}$ Water Resources Section, Delft University of Technology, PO Box 3015, 2601 DA, Delft, The Netherlands
}

\begin{abstract}
This paper contributes to the ongoing discussion on the implementation of water reforms in rural African waterscapes and explores how farmers in a tertiary catchment in Zimbabwe react to these reforms. It shows how privileged farmers have jumped the water queue by moving their agricultural activities upstream where they illegally divert water straight from the river, while downstream, in the smallholder irrigation scheme, farmers resort to rainfed farming. This unforeseen consequence of the 1998 water reform process, implemented during the economically unstable decade that followed, is explained by adopting a socio-nature approach. Empirical field data as well as processed satellite images are presented and the politicized implications of water reform processes in the Zimbabwean context are discussed. Besides the need to critically examine the content of water reform processes, more attention is needed for understanding what happens to the water that escapes stipulated plans, prescribed rules of control and visible decision-making arenas.
\end{abstract}

Keywords: irrigation, water reforms, river basin management, socio-nature, Zimbabwe

\section{INTRODUCTION}

Anyone visiting Zimbabwe during the peak of the economic meltdown in 2008 would have been astonished by the orderly lines of people patiently queuing day-in day-out for literally everything: from bread and eggs to cash and fuel. However, such was not the case for water. During our research on the implications of the water reform process, initiated in 1998 and implemented during the economically unstable decade that followed, we observed that those who could afford to jump the queue, moved their agricultural activities upstream in a catchment to secure access to water. This paper attempts to explain this unforeseen response to, and outcome of, the water reform process, and critically analyses the consequences for access to water in the catchment. In this way, the paper contributes to the ongoing discussion on the implications of water reform processes for rural African waterscapes (Wester et al., 2003; Zawe, 2006; Swatuk, 2008; Kemerink et al., 2011; 2013; Komakech et al., 2011; Van Koppen et al., 2014).

Building on extensive previous research (Bolding, 2004), the Nyanyadzi catchment, located within the Save river basin in the eastern part of Zimbabwe, is used as a case study for this paper. The findings presented are based on in-depth semi-structured interviews with 22 water users within the case study area and 8 government officials involved in the water reform process, including agricultural extension officers and representatives of the catchment council and the Zimbabwe Water Authority. The interviews were carried

\footnotetext{
$\dagger \quad$ Deceased 31 August 2015

* To whom all correspondence should be addressed.

푠 Tel: + 31152152 371; e-mail: j.kemerink@unesco-ihe.org

Received 6 July 2016; accepted in revised form 12 June 2017
}

out between October 2011 and January 2012, with follow-up interviews and visits to the catchment in 2013 and 2015, and addressed, amongst other issues related to personal histories of interviewees, water use practices and involvement in decision-making processes, and the implications of the water reforms on interviewees' access to water. The interviewees were selected using the purposive sampling method (Babbie and Mouton, 1998) to obtain input from various categories of water users and other relevant actors, as well as different age, class and gender groups. The interview narratives have been made anonymous to ensure confidentiality in the light of the ongoing political sensitivities between various actors in the case-study area. The findings of the interviews were cross-checked through 8 focus group discussions with various groups of farmers and water managers, field observations, analysis of relevant documents such as policies, meeting minutes and databases, comparison with existing literature and by consulting scientists and non-governmental organizations (NGOs) active in the region. In addition, the data collected through interviews on the physical changes within the waterscape have been compared with publicly available satellite images.

The paper first provides a detailed narrative of the catchment, including an analysis of the historical and institutional context. Thereafter, the water reform process as envisioned at national level is described as well as how it unfolded within the case study catchment. This is followed by an analysis of how the Nyanyadzi waterscape has physically changed during the implementation of the water reform process and what the implications are for the different groups of water users in the catchment. The concluding section reflects on the unintended and unforeseen outcomes of the reform process in Nyanyadzi catchment and the implications thereof. 


\section{Setting the scene}

The Nyanyadzi River in the eastern part of Zimbabwe is a tributary of the Odzi River just before the confluence with the Save River (Fig. 1). The water within the Nyanyadzi catchment originates from the Chimanimani Mountains on the border with Mozambique. The Nyanyadzi catchment carves out an $800 \mathrm{~km}^{2}$ area with an average rainfall of $1200 \mathrm{~mm} / \mathrm{yr}$ in the upstream part of the catchment and less than $500 \mathrm{~mm} / \mathrm{yr}$ downstream (Magadlela, 1999; Bolding, 2004). Most of the streams within the catchment are perennial with extremely low flows during winter, from May to August, while most rain falls in summer between November and March.

Contrary to claims by the first European settlers at the time that they arrived in the early 1890s, the upstream parts of the Nyanyadzi catchment were densely populated by people of the Ndau tribe, while in the lower parts of the catchment, Ndau settlements were clustered along the river (Bolding, 2004). The Ndau mainly relied on a combination of rotational agriculture of dry lands and permanent cultivation of the wetlands along the river banks. In some locations hand-dug furrows were used to divert water from the rivers for supplementary irrigation (Bolding, 1996). The agricultural land in the catchment was customarily owned and managed by the chiefs with plots being allocated to families for farming (see Andersson, 1999, for a detailed narrative on land tenure and allocation practices in a neighbouring district).
In 1923, Zimbabwe became a self-governing colony of the British Empire and in 1927 the colonial authority endorsed a Water Act that granted private ownership rights based on three main principles, namely: riparian rights, which restricted water rights to land owners; priority date rights, which meant water rights were granted based on first-come first-served basis; and perpetuity, which entailed that rights were granted for an infinite time and could only be revoked under special circumstances (Jaspers, 2001; Manzungu and Machiridza, 2009).

In 1934, the colonial government initiated the construction of the Nyanyadzi Irrigation Scheme in the most downstream part of the catchment. Although originally established to mitigate recurrent famine and developed with the aspiration to demonstrate the potential of 'modern' African agriculture, this scheme facilitated the removal of the native African population from the fertile upstream lands (Bolding, 2004; Manzungu and Machiridza, 2009). Nyanyadzi scheme started off with one block, which is currently referred to as Block C, but expanded into three more blocks further downstream; Block A in 1940, Block B in 1945 and Block D in 1951 (Fig. 1). Once the scheme was completed, the total command area of the irrigation scheme covered $412 \mathrm{ha}$, with the first generation of farmers irrigating 1.0 to $1.2 \mathrm{ha}$ each. Similar to the tenure regime in the reserves, the families that were settled in Nyanyadzi scheme obtained user rights over land and not full ownership rights. Moreover, Nyanyadzi plot holders could be evicted by the

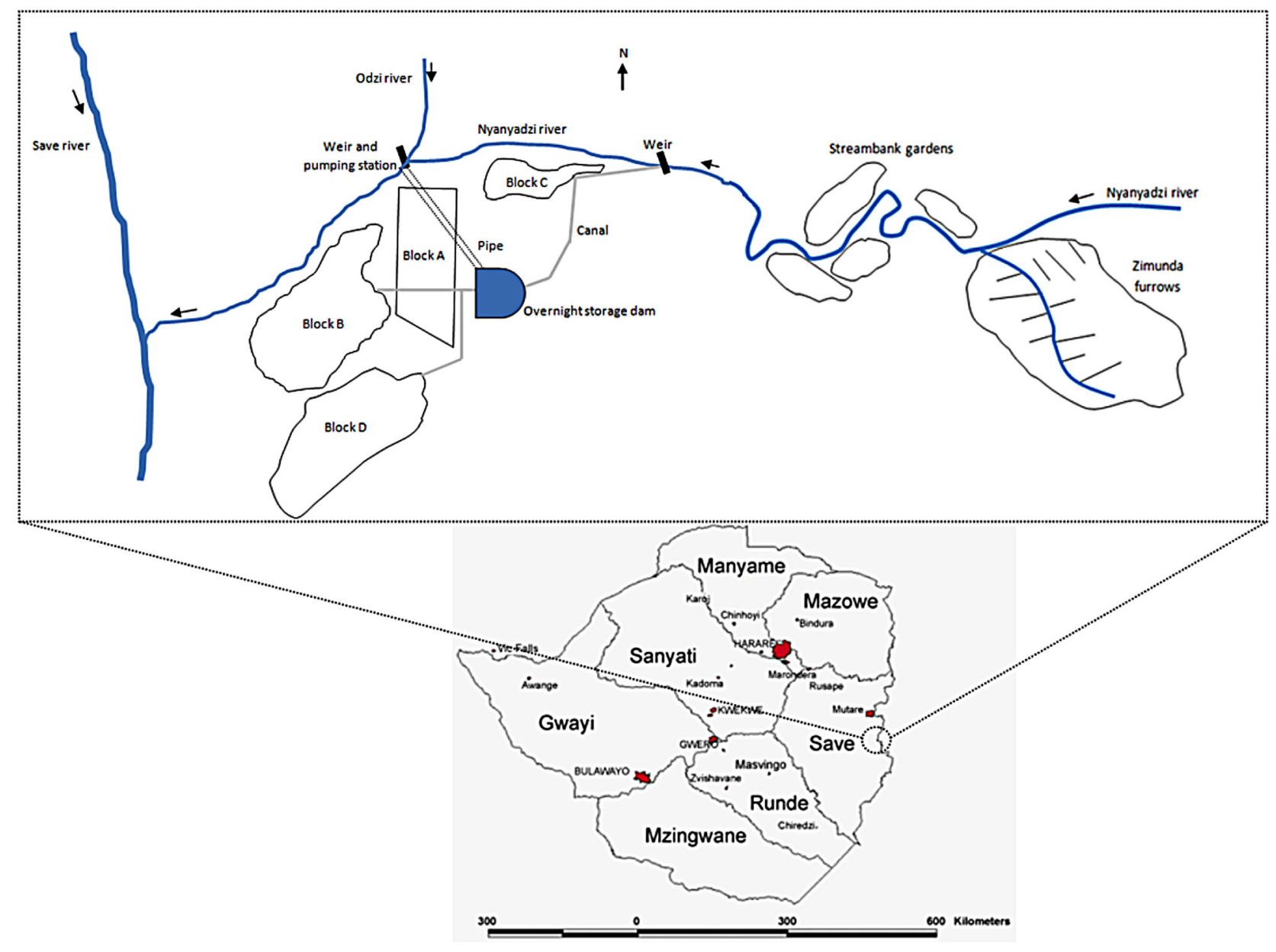

Figure 1

Sketch of the Nyanyadzi river catchment including its location in Zimbabwe 
government-appointed scheme manager in case their activities deviated from stipulated cultivation practices (Bolding, 2004).

In 1937, the irrigation scheme obtained the first water right within the Nyanyadzi catchment under the 1927 Water Act, allowing the scheme to abstract $283 \mathrm{~L} / \mathrm{s}$ to irrigate 400 ha. Even though the then prevailing Water Act recognized the priority date principle, the priority given to the irrigation scheme was limited to the drainage area covered by the upstream native reserves to ensure that White farmers further upstream in the catchment could still apply for water rights without needing to consider the water right of the Nyanyadzi Irrigation Scheme (Bolding, 2004). The water was diverted at a weir that was built across the Nyanyadzi River several kilometres upstream of Block $\mathrm{C}$ and was conveyed by a gravity system of canals and gates to the fields. Water supply to the irrigation scheme gradually diminished due to the increased (unofficial) water use by European settlers upstream, while simultaneously the command area expanded. Consequently, water availability became a serious concern within the irrigation scheme. Since 1942 plans have existed to put a dam on Nyanyadzi River to alleviate the water scarcity within the scheme (Bolding, 2004). When the dam failed to materialize, Blocks A, B and D secured additional water released from the Odzi river in 1957 to address the most pressing needs. This water was initially pumped by diesel-run engines from a (temporary) weir at the confluence of the Odzi and Nyanyadzi rivers and conveyed by a pipe to Block A. Later, water released from Osborne Dam reservoir $200 \mathrm{~km}$ upstream was diverted by a pumping station run on electricity and the pipe was extended to push the water into an overnight storage dam from where it was channelled to Blocks A, B and D (Fig. 1).

Within the Nyanyadzi Irrigation Scheme mainly maize was grown in summer and wheat and beans were cultivated during the dry winter months. In the first decade, the agricultural production of the irrigation scheme was limited, but from the 1950s, the yields increased (see also Andersson, 2007). Meanwhile, water rights were granted between 1939 and 1952 to 10 White-owned farms located upstream of Nyanyadzi, allowing the farmers to abstract $77 \mathrm{~L} / \mathrm{s}$ of water to irrigate 114 ha (Bolding, 2004). As more Africans were settled into the scheme and plots were divided among younger generations, plot sizes in the Nyanyadzi Irrigation Scheme decreased. This forced the irrigators to cultivate additional land outside the irrigation scheme or search for alternative livelihoods.

Resistance against the colonial state gained momentum during the 1960s and 70s and the catchment became an important nursing ground for nationalist political movements such as the Zimbabwean African National Union (ZANU, in 1988 merged into ZANU-PF). Redressing the racial dispossession of land became the main slogan to mobilize people into the armed struggle against the colonial regime (Zawe, 2006). Towards the end of the armed struggle, just before independence, Nyanyadzi catchment was basically controlled by ZANU activists and White settlers had vacated their farms (Bolding, 2004). A few years after independence in 1980, the ZANU-led government resettled smallholder farmers on some of the remaining White-owned farms in the middle reaches of the Nyanyadzi catchment, creating the village of Zimunda (Fig. 1). In this settlement scheme, farmers divert water from the Nyanyadzi River via unlined canals locally referred to as furrows. The establishment of this scheme was corroborated by a resident from Zimunda village who said 'soon after independence in 1980 we were told to register our names for consideration for land redistribution.
I was one of the first people to be settled here in 1983, with the government coming in with tractors and earth-moving equipment to clear and flatten the land to create fields for us' (interview FI4/TD). None of the plots came with water rights that were obtained by the previous White owners of the land. To secure access to water, 30 furrow irrigators in the Nyanyadzi catchment and 9 furrow irrigators in the Zimunda scheme were granted (individual) water rights in the 1980s and early 1990s. These water rights were applied for through the District Administrator, who mediated water conflicts emanating from upstream raids to bring water to Nyanyadzi Irrigation Scheme. However, in practice, an estimated hundred furrows in the catchment extracted water from the river, irrigating up to 250 ha of land by the end of the 1990s (Bolding, 2004).

Even though attempts were made to increase involvement of farmers in the operation and maintenance, the Nyanyadzi Irrigation Scheme had for various reasons been controlled by the government from its establishment until 1997, when the fiscal deficit forced the government to hand over most of the costs and management responsibilities under the so-called irrigation management transfer policy (Bolding, 2004; Zawe, 2006). The Irrigation Management Committee (IMC) of the Nyanyadzi Irrigation Scheme, which had been established in 1980 , became the main responsible entity for the irrigation scheme. This committee comprised of 8 elected members from the farmers' community, 2 representatives from each block. Elections were held every 5 years and overseen by agricultural extension officers from the government. Even though the farmers had paid so-called maintenance fees for several decades already, now they became responsible to cover the full costs for maintenance and operation of the scheme, including payment for the water released from the Osborne Dam and the electricity bill of the pumping station that supplied water to Blocks A, B and D. The recurrent water shortages in the scheme together with the increased costs for accessing water led to tensions between the farmers in the Nyanyadzi Irrigation Scheme and the upstream water users, especially the Zimunda furrow irrigators (see also Bolding, 2004).

\section{THE ZIMBABWEAN WATER REFORMS}

Triggered by droughts in the early 1990s and encouraged by international donors, a new water law was enacted in 1998 with the aim to reform the water sector and specifically to redress inequities in access to water (Jaspers, 2001; Manzungu and Kujinga, 2002). The new legislation abolished private ownership of water and introduced a conditional licensing process for any water use other than basic domestic. In this licensing process the perpetuity, prior appropriation and riparian right principles are no longer recognized (Jaspers, 2001). Moreover, the 1998 Water Act states that permit holders must pay for water, and stipulates that the tariff, and changes therein, have to be justified based on 'the cost of providing, operating or maintaining the service concerned, any proposed improvements to any service or facility; and any other relevant economic factors' (GOZ, 1998b, article 30-2). The Water Act also provides room for progressive tariff setting by stating that '... different charges may be fixed for the sale of water to different classes of persons or for different uses. Provided that, ... there shall be no discrimination between persons on the grounds of race, tribe, place of origin, political opinion, colour, creed or gender.' (GOZ, 1998b, article 30-5).

Under the 1998 Water Act, seven river catchments were identified based on hydrological boundaries, each to be 
governed by catchment councils. The council members are elected and/or appointed stakeholder representatives, who have to, amongst others, develop integrated plans for the catchments, revise and review water allocation, issue permits and collect water levies (GOZ, 1998a:21; see also Manzungu and Kujinga, 2002). The councils have the authority to revoke or revise permits as they see fit, for instance in case of overabstraction or inequity in allocation (GOZ, 1998a:28). Each river catchment is further divided into sub-catchments with councils responsible for the day-to-day management of the water resources, including the regulation and supervision of the lawful use of water. Permit holders pay fees to the subcatchment councils, which are entitled to levy additional fees for services they provide. Members of the sub-catchment council are elected and should represent the different stakeholders in the area under its control (GOZ, 1998a:24; see also Jaspers, 2001).

At national level, the Zimbabwe National Water Authority (ZINWA) has been established to advise the minister responsible for water on the formulation of national policies and frameworks relevant for the planning, management and development of the country's water resources. ZINWA owns, operates and maintains national dams and the water held therein. ZINWA also manages the Water Levy Fund that is meant to promote water resources development and water service provision, in particular for the construction of water infrastructure in areas that have been disadvantaged during the colonial era (Makurira and Mugumo, 2003). The fund's revenue comes from the fees paid by permit holders, payment for water sold from ZINWA dams and any other money the government receives or allocates for managing water resources (GOZ, 1998b: 33-39).

The water reform process in Zimbabwe coincided with changes in the land reform policies in an attempt to speed up the redistribution of land from the Wite settlers to the native African population as little progress had been made since Independence (Zikhali, 2010). Under pressure of international donors, the land reform process had so far been bounded by neoliberal principles such as willing-buyer, willing-seller and compensation of loss of property and income according to market prices. In 1992, the government adopted an Act that abandoned the willing-buyer, willing-seller principle to force the acquisition of White-owned property to resettle smallholder farmers. However, when progress remained slow, frustration led to illegal ZANU-PF-encouraged land invasions of White-owned commercial farms. The land appropriated under this so-called fast-track land reform programme was nationalized in 2005, depriving the former landowners of the right to appeal in court against the expropriation of their land or demand financial compensation (Zawe, 2006; Svubure et al., 2011). In response to this fast-track programme, international donors, who had provided financial and technical aid to implement the water reform processes, withdrew their support from Zimbabwe. This sudden withdrawal, combined with international economic sanctions against the government, triggered a meltdown of the national economy, subsequently stalling the implementation of the water reform process (Makurira and Mugumo, 2003). More importantly, the financial basis for the new institutional set-up introduced by the reform process and the required investment in water infrastructure had always leaned on the sustained activities of commercial farmers, whose payments for water would generate income for the Water Levy Fund and the catchment councils. This financial basis was erased by the land invasions.

\section{Unfolding the water reforms in Nyanyadzi catchment}

As a result of the water reforms, the Odzi Sub-Catchment Council (OSCC) became the main regulator of water in Nyanyadzi catchment from 1999 onwards (Kujinga, 2002). The OSCC has an office in Mutare, a town $100 \mathrm{~km}$ away from Nyanyadzi (Fig. 1), and falls under the authority of the Save Catchment Council (Kujinga and Manzungu, 2004). The OSCC councillor who currently represents the farmers in the Nyanyadzi Irrigation Scheme is a farmer in another irrigation scheme. She was appointed without consultation with the Nyanyadzi IMC after the previous councillor passed away and by 2015 she had not visited the Nyanyadzi Irrigation Scheme. During the 2011 OSCC annual general meeting, participants claimed that some councillors had long lost their legitimacy as they failed to represent their constituencies by not communicating to them what has been discussed and agreed in the council meetings and vice versa, while the councillors complained that they did not have enough resources to consult the farmers they represent (Chinguno, 2012; see also Kujinga, 2002). The small-scale farmers who are abstracting water without a permit have no representative in the OSCC.

Moreover, from analysing the minutes of several Save Catchment Council and OSCC meetings, as well as attending the 2011 OSCC annual general meeting, it becomes clear that the council's primary focus is on managerial issues. A few councillors, mainly those representing the White commercial farmers in the Odzi catchment, dominate the meetings and continuously raise questions about administrative and financial matters (Chinguno, 2012; see also Kujinga, 2002, and Kujinga and Manzungu, 2004 for similar findings in earlier studies). As a result, catchment plans for water allocation were not yet developed by 2015 , nor have monitoring plans for water use been implemented. Another drawback for developing catchment plans is the outdated database registering water permits in the catchment; for approx. 13\% of the total 4162 permits issued in the Save catchment, the current permit holder is unknown; nor is the amount of water they are entitled to known. This also applies to 4 of the 41 water permits issued within the Nyanyadzi catchment. For those permits where the permit holders are known, it is unclear if the actual abstraction is according to the permitted use and if the permit holders have fulfilled their duties, such as paying the applicable fees. The bias towards internal organizational matters rather than implementing the council's core activities of regulating water use and supervising the day-to-day management of the water resources is also reflected in the OSCC budget allocation for 2012. The expected income for 2012 for Odzi catchment from collected water fees paid by permit holders was estimated at about 300000 USD (excluding an estimated 265000 USD of arrears from non-paid fees). As the OSCC has to pay approximately 100000 USD to the national Water Levy Fund, it is left with an annual budget of about 200000 USD. The 2012 budget shows that about $47 \%$ was expected to be spent on staff salaries, meeting venues and allowances for OSCC councillors, $18 \%$ was allocated for office consumables, office equipment, administration and contingencies, 24\% for transportation, including purchasing of council vehicles, and the remaining $11 \%$ for awareness workshops and the annual general meeting.

In response to the OSCC budget allocations, the Save Catchment Council Manager stated that 'councillors and catchment council staff must value the water users as they are the life givers of the catchment and sub-catchment councils' (OSCC, 2010). The farmers, however, do not understand why 
they need to pay water fees without receiving any services from the OSCC that improve their access to water, which according to the Water Act is a prerequisite for charging water fees. A traditional leader argued in a meeting with the water authorities on the topic of charging water fees: 'neither the water authority ZINWA nor the relevant sub-catchment, OSCC, has built a dam nor added anything to the water' (Interview IFD3/TD). Similarly, a Nyanyadzi irrigator stated that 'their (ZINWA and OSCC) message is always pay, without explaining what the money is for. They forget that the river is ours. Had it been they had put a dam on the Nyanyadzi River, we would understand what the money is for' (focus group discussion IMC). In addition to the disagreement on budget allocations, several incidences of financial mismanagement within the OSCC have been reported, including the payment of bonuses to councillors without prior approval and the omission to account for the sale of a vehicle owned by the council (Chinguno, 2012).

\section{Redistribution of entitlements to water}

The water reforms have altered entitlements to water and, consequently, affected the distribution of water among the various water users within the catchment. The least has changed for the furrow irrigators around Zimunda. The existing water rights that 9 furrow irrigators obtained under the previous legislation have been automatically converted into water permits. Even though the permits are conditional on payment of the water fees, the irrigators so far have not paid for the water they abstract, as they claim that most of the harvest is used for subsistence rather than commercial purposes. With no metering system in place to monitor the actual abstractions, it is difficult for the authorities to enforce the payment for water. Another 11 Zimunda irrigators, who did not have water rights under the previous water act, have continued to abstract water without formal entitlement. Even though they risk a penalty for abstracting water without permit, the limited monitoring of the water abstractions by the OSCC have so far allowed them to continue their water use practices. The water used to cultivate gardens on the river banks used to fall under primary use and thus be exempt from requiring a water right. However, under the 1998 Water Act, this water use is deemed illegal since it is no longer defined as primary use (GOZ, 1998a:3). Moreover, the Environment Management Agency claims that the practice of irrigating on river banks causes erosion, soil degradation and siltation of the river bed. As a result, these farmers are under pressure to abandon their farming activities. In response, they have resorted to abstracting water at night to avoid confrontation with the authorities.

The water reforms have had the biggest implications for the farmers in the Nyanyadzi Irrigation Scheme. They enjoyed priority rights, albeit limited, under the previous Water Act, which was extinguished by the 1998 Water Act. Being located furthest downstream in the catchment, they were removed from first position (on paper) and placed last in the water queue on the Nyanyadzi River. This has especially affected the water availability in Block $C$ that fully depends on the river for its supply. Furthermore, since the irrigation scheme has a gauging station at the river intake and the pumping station is also equipped with a water meter, it is easier for the authorities to charge the irrigation scheme fees for the abstracted water compared to the unmetered users upstream. The scheme facilitates the payment of fees; rather than dealing with a large number of individual farmers, the authorities can pressure the IMC to pay the fees, while the IMC in its turn can refuse to allocate water to farmers who have not fulfilled their obligations. This has forced farmers to pay the water fees or to bribe the water operators. ZANU-PF affiliated farmers argue that the IMC is implementing the political agenda of the opposition party, including charging high fees for water use and harassing farmers to pay. They claim that the ZANU-PF-led government does not demand historically marginalized farmers to pay and instead provides handouts to them. In contrast farmers affiliated with the opposition argue that the excessive amount of money they need to pay to access water is a punishment from ZANU-PF for electing a candidate from the opposition party for this constituency during the 2008 general elections, in which ZANU-PF for the first time since independence lost its majority in Parliament. Either way, the price they pay to access water is relatively high compared to other water users in the catchment and this price continues to increase: from 5 USD per irrigated acre in 2012 to 17 USD in 2015.

The situation has worsened since the dollarization of the Zimbabwean economy in 2009 in an attempt to combat the hyperinflation as result of the economic meltdown. By the end of 2011 the Nyanyadzi Irrigation Scheme farmers had built up a collective debt of 28000 USD with the electricity company. As a result, the electricity supply was disconnected in October 2011, leaving the irrigation scheme to solely rely on the little water that was supplied by the Nyanyadzi River. Since then only Block $\mathrm{C}$ received some water to irrigate plots, while the other blocks completely dried up. The acute water shortage led to an outright refusal to pay water fees, increasing the debt of the irrigation scheme with ZINWA to 17000 USD for unpaid water fees. During the campaigns for the 2013 presidential elections, the debts were cancelled by the government in an attempt to win back the constituent seat in Parliament.

\section{Reordering the Nyanyadzi waterscape}

The shifts in institutional arrangements during the last century have changed the waterscape of Nyanyadzi catchment. In the pre-colonial time, mainly the upstream part was inhabited and the naturally available soil moisture in the river banks was permanently used for gardening, while the soil moisture in the drier parts of the catchment was only used on a rotational basis for subsistence farming. Only a few unlined furrows were constructed for supplementary irrigation by smallholder farmers. The colonial time was marked by a move downstream as a result of forced relocation of the indigenous population. A racially segregated waterscape was consolidated through water infrastructures that provided water to the White-owned largescale commercial farms in the upstream parts of the catchment and the regimented smallholder plots in the downstream irrigation scheme. In the middle reaches of the catchment, soil moisture was permanently used for subsistence farming, both in the drier parts of the catchment as well as on river banks. The post-colonial era introduced the subdivision of the large-scale farms into smallholder plots and the increased number of lined and unlined furrows in the upper and middle reaches of the catchment for irrigation throughout the year. This resulted in water scarcity within the downstream irrigation scheme, especially for the farmers located in Block $\mathrm{C}$ during the dry winter months.

The water reform process, initiated by the 1998 Water Act and affected by political and economic turmoil, has also left its mark in the Nyanyadzi waterscape. The changes in entitlements and the difference in costs for accessing water as result of the 
reform process, in combination with the absence of investments in water infrastructure, has triggered a move upstream; farmers who managed to obtain land through the traditional tenure system have jumped the water queue by leaving the downstream irrigation scheme and establishing irrigated plots further upstream along the river banks. These farmers often rent out the life-long lease they have on the plots in the irrigation scheme. The District Administrator has tolerated these private transactions that are inconsistent with the law, and thus somehow legitimized the transfer of land to wealthy, often politically well-connected, individuals. Those farmers who could not afford to jump the water queue by securing land upstream along the river have resorted to practising rain-fed farming within the irrigation scheme. A farmer explains: 'we now practise dryland agriculture in our irrigation scheme and the scheme has since relocated to the river' (Interview G1).

The proliferation of irrigated plots along the river banks and the drying up of the downstream irrigation scheme as claimed by the interviewees has been confirmed with satellite images. The Normalized Difference Vegetation Index (NDVI) on processed satellite images of several years between 2004 and 2014 shows a gradual yet noticeable increase in green vegetation along the river bed over consecutive years. Figure 2 shows the NDVI values on processed satellite images of a $6.5 \mathrm{~km}$ river section that starts $0.5 \mathrm{~km}$ upstream of the weir that diverts the water into the Nyanyadzi Irrigation Scheme. The NDVI value ranges between -1 and +1 with values above 0.4 indicating green (living) vegetation and values below 0.4 , visualized in the colours yellow to red, indicating very dry (non-living) vegetation to bare soil. The satellite images are dated midSeptember which is towards the end of the dry (winter) season and all green vegetation must be either irrigated crops or riparian vegetation. Comparing the images of 2005 (Fig. 2a) with the image of 2014 (Fig. 2b), the latter shows an increase of green vegetation along the riverbed. Aerial pictures confirm that these are irrigated gardens rather than an increase in natural riparian vegetation (Fig. 2c). Since the satellite images are relatively coarse (1 pixel covers an area of $30 \mathrm{~m}$ by $30 \mathrm{~m}$ ) while the gardens typically cover $500 \mathrm{~m}^{2}$ (less than 1 pixel), the increase can be considered as significant in the sense that completely new gardens have been established and/or existing gardens have been substantially increased in size.

Whereas in the irrigation scheme, both the winter and the summer harvests regularly fail due to a shortage of water, the (a)

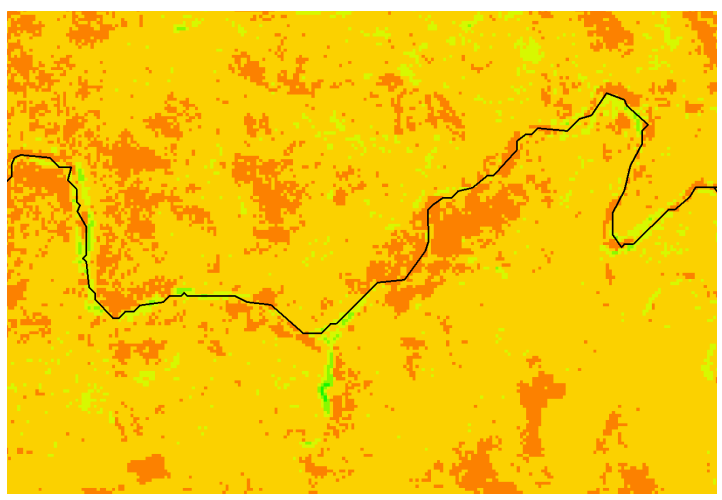

(b)

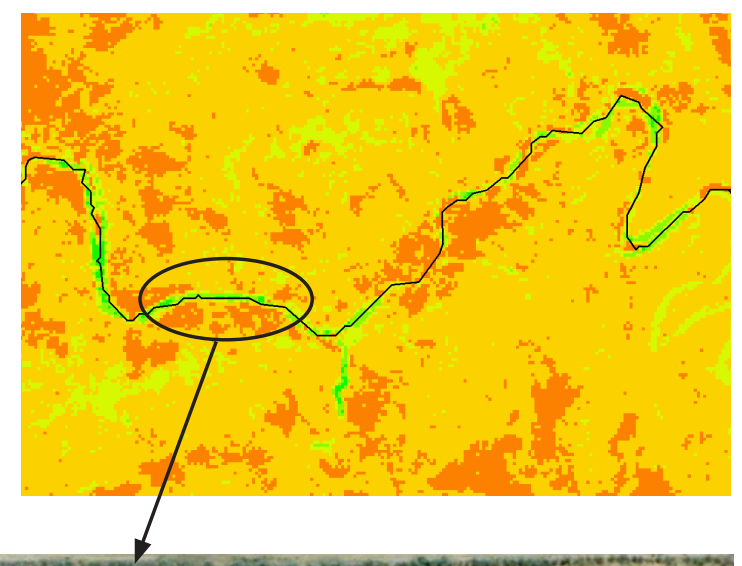

(c)

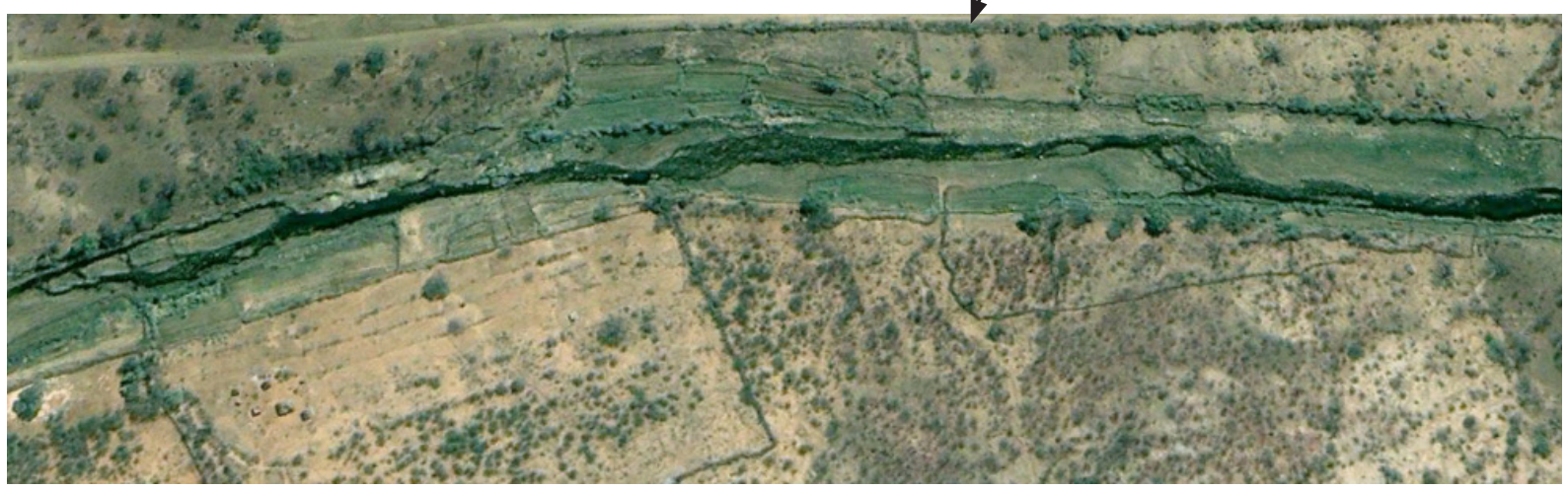

\section{Legend}

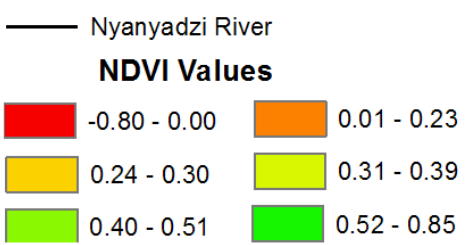

Figure 2

Satellite images of Nyanyadzi River section upstream of intake of Nyanyadzi Irrigation Scheme: (a) NDVI values 22 September, 2005 (Earth Explorer); (b) NDVI values 15 September, 2014 (Earth Explorer); (c) satellite image of area circled in (b), 24 November, 2014 (Google Earth) 
plots along the river can be harvested up to 3 times per year. Not only has the water distribution in the waterscape been altered due to the reform process, but the plot sizes have also changed. In the past, the average plot size in the Nyanyadzi Irrigation Scheme decreased as a result of subdivision of plots amongst heirs (Bolding, 2004). However, the average plot sizes have increased since the water reforms as a few people have 'bought up' the land from people who left the irrigation scheme. These actors who obtain the vacant land are locally influential persons affiliated with ZANU-PF who, through patronage, manage to obtain the little water that is still available in the irrigation scheme and/or who anticipate an increase in the availability of water within the irrigation scheme in the near future. Along with these new actors, traders have entered the irrigation scheme and now control considerable parts of the agricultural business in and around the scheme, including changing the main cropping pattern to sugar beans and tomatoes. Meanwhile some plot sizes along the river have also increased considerably; where there used to be small vegetable gardens, now demarcations of individual plots of up to 0.5 ha are visible (Chinguno, 2012; see also Fig. 3). Some of these plots are not located on the banks of the river, but in the river bed itself (Fig. 3a, c). This has potentially detrimental consequences for river flows and soils, but also leaves these farmers vulnerable to destruction of their crops by seasonal flash floods as occurred for instance in December 2011. It should be noted that these plots along the river are not exclusively in use by farmers who moved out of the Nyanyadzi Irrigation Scheme, but include people coming from (peri-)urban settlements in search of alternative livelihoods in response to political turmoil and economic decline (Bratton and Masunungure, 2006).
The financial challenges within the Nyanyadzi Irrigation Scheme have also reordered the waterscape. Whereas in the past, Block $\mathrm{C}$ was disadvantaged as it only received water from the dwindling Nyanyadzi River, now it is the other blocks in the irrigation scheme that struggle more; no water is pumped anymore from the Odzi River and the water from Nyanyadzi River is fully used by the farmers in Block C. This is clearly visible on the aerial photographs in Fig. 4:, during the start of the winter cropping season of 2013 Block C shows several irrigated plots on which crops grow (Fig. 4a), while Block A directly downstream does not show any sign of irrigated crops and has completely run dry (Fig. 4b). Field data also confirmed that during the 2011-2012 summer cropping season, Block $\mathrm{C}$ was the only block to realize a reasonable harvest, while in the other blocks the harvest almost completely failed as result of water scarcity. Farmers in Block $\mathrm{C}$ argue that they do not let water flow to the downstream blocks as the little water available in the system will not reach these blocks (focus group discussions IFC), though farmers from Blocks A, B and $\mathrm{D}$ assert that farmers in Block $\mathrm{C}$ claim priority rights over the water originating from Nyanyadzi River. Block C farmers reason that, as descendants of farmers that first settled in the irrigation scheme with forefathers who vacated ancestral land to make place for the scheme and the irrigation canals, they can claim priority rights to the water (see also Bolding, 2004).

The NDVI values towards the end of the cropping season in September 2013 confirm that hardly any irrigation took place that year, as only a few signs of green vegetation are visible (Fig. 4c). The cancellation of the debts for the electricity bill and water fee in the run-up to the presidential elections in July 2013 came too late to avoid failure of the harvest. (a)

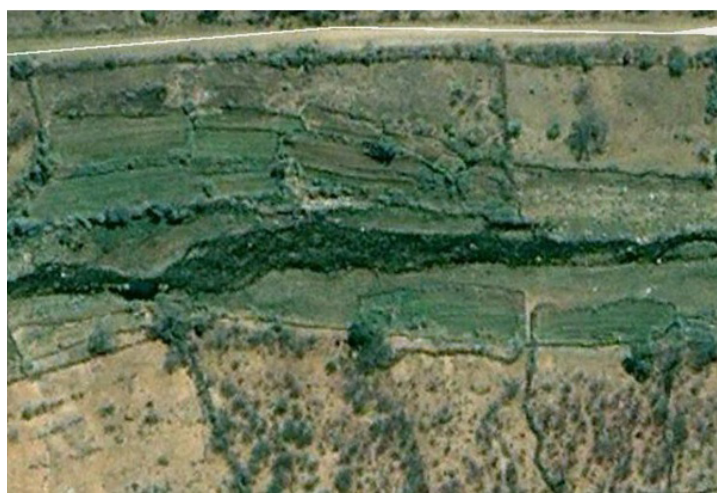

(b)

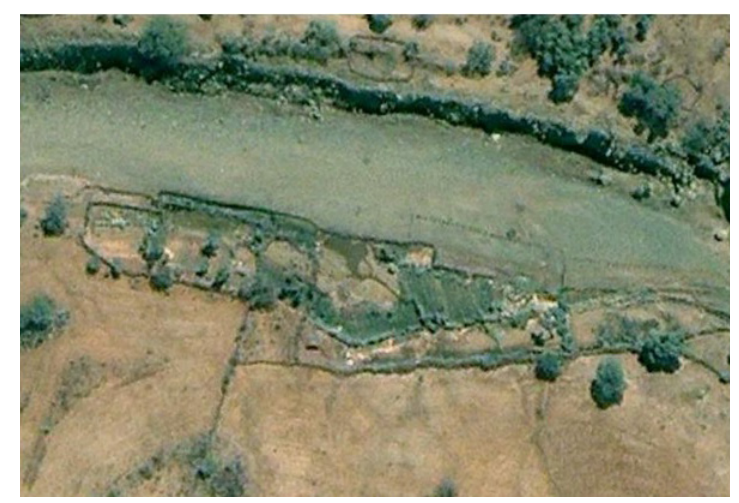

(c)

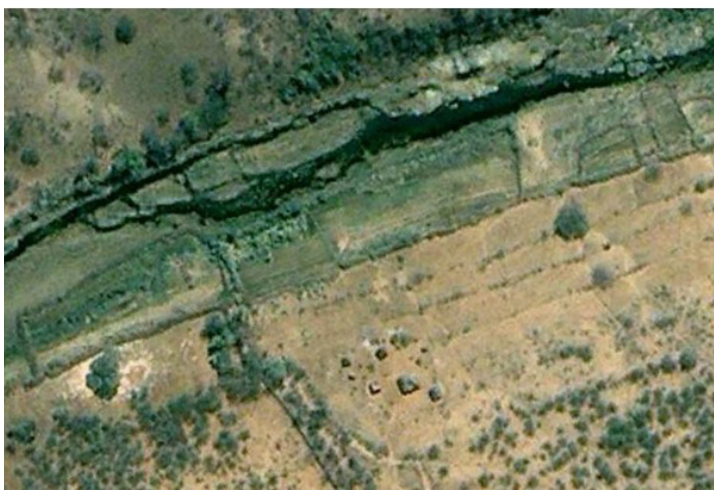

Legend:

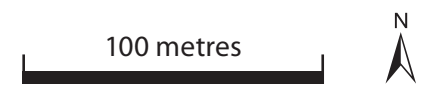

Figure 3

Satellite images of irrigated gardens upstream of the intake of Nyanyadzi irrigation scheme (Google Earth, 2015) 
(a)

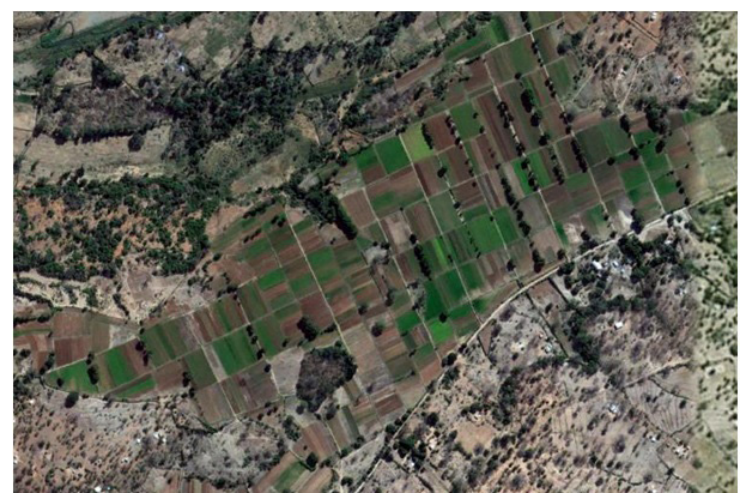

(c)

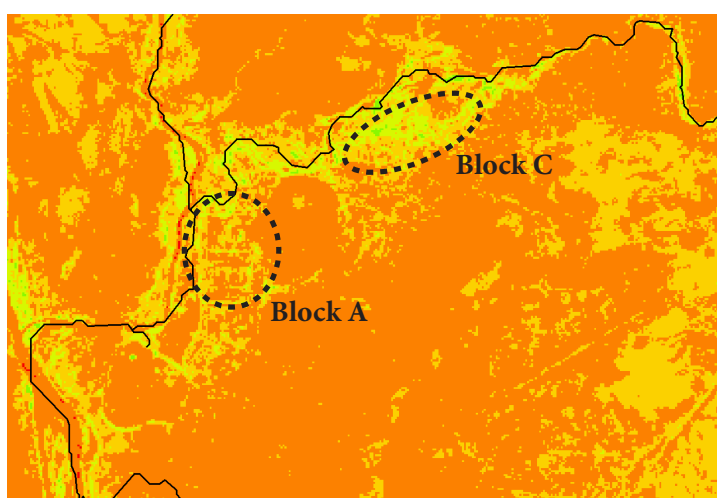

Legend

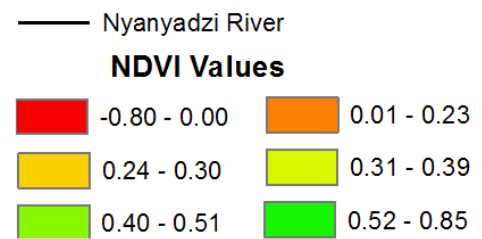

(b)

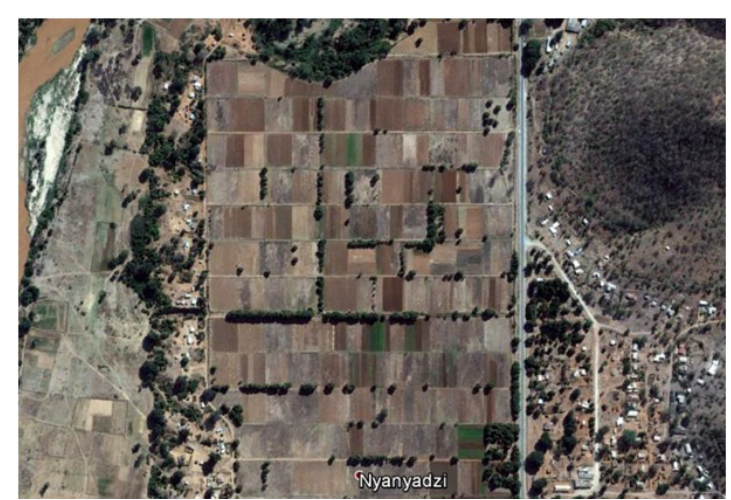

(d)

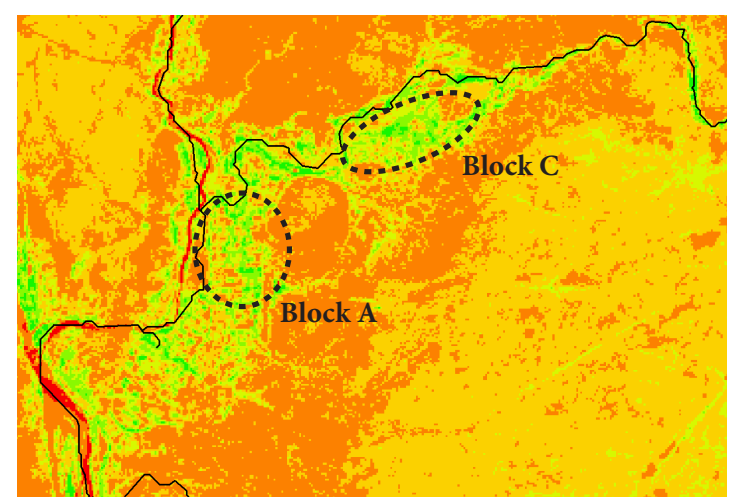

Figure 4

Satellite images of Nyanyadzi Irrigation Scheme: (a) satellite image Block C on 21 June 2013 (Google Earth); (b) satellite image Block A on 21 June 2013 (Google Earth); (c) NDVI values for September 12, 2013 (Earth Explorer); (d) NDVI values for September 15, 2014 (Earth Explorer)

The NDVI values in the same month a year later, in 2014, show a completely different picture; irrigated plots are clearly visible even in the tail-end of the irrigation scheme (Fig. 4d). It thus seems that the government intervention to revoke the arrears especially benefitted those actors who obtained the land vacated by farmers that left the irrigation scheme in the preceding years in response to the multiple failures of the harvest due to the acute water shortage.

\section{DISCUSSION}

This article shows that the Nyanyadzi waterscape is constantly reordered as a result of intimately linked social and natural processes. Throughout history, different socio-political eras have left visible traces on the Nyanyadzi waterscape in the form of unequal social relations that have materialized in disparate access to land and water resources, often consolidated by water infrastructure. The availability, type and lay-out of water infrastructure, even in its malleable and unplanned form, actively opened certain trajectories and foreclosed other pathways for the catchment (see also Van der Zaag and Bolding, 2009; Ahlers et al., 2011; Meehan, 2014). Nevertheless, the reflection of injustices in the Nyanyadzi waterscape also engendered contestation that changed these relations into new, not necessarily more equitable, social relations. Moreover, this case shows that, in struggles for access to and control over natural resources, the physical environment is not simply an arena but plays an active role in constituting the outcomes by shaping human-environmental dynamics (see also Zimmerer and Bassett, 2003). After all, the materiality of water, especially its notoriously capricious nature and its forceful and directional flow, determined the differences in potential for, and risks of, agricultural production in the various localities in the catchment. The current waterscape of Nyanyadzi is a manifestation of continuous socio-nature processes in which legacies of former institutional arrangements as well as contemporary interventions shape, and are shaped by, the physical environment, resulting in different outcomes for the various water users in the catchment (see also Swyngedouw, 1999; Di Baldassarre et al., 2013). The water reform process initiated in 1998 contributed to a further reordering of the waterscape in unexpected ways and with potentially longlasting consequences, both for water users as well as the environments they live in. 
The Zimbabwean water reform process has been influenced by a global change in public policies for water resources management, in which the main focus of governments shifted from investing in the development, operation and maintenance of water infrastructure to a focus on managing water resource systems by stipulating regulatory frameworks for water allocation (Cleaver and Elson, 1995; Lowndes, 2005; Kemerink, 2015). Within this revised role, the Zimbabwean Government, realizing the need to redress the racial legacy of the colonial period and in line with the global trends in thinking about water resources management, abolished the priority date, riparian right and perpetuity principles for allocating water resources. The government reasoned that by abandoning these principles, water would become more accessible for new users, which would include the previously dispossessed indigenous African population. Nevertheless, the Zimbabwean Government also recognized the importance of, and inequity in, access to water infrastructure, and therefore established a national fund to stimulate infrastructural development in previously disadvantaged areas. In contrast to the exclusive focus on, and neoliberal inclination of, institutional change processes that have been adopted elsewhere (Kemerink, 2015), this progressive, physical-oriented measure gave the government the opportunity to directly invest in infrastructure and as such steer the direction of water flows.

Despite this progressive approach, the reality on the ground is that water users in Nyanyadzi catchment pay water fees which are used mainly to cover the overhead costs of a heavy organizational structure at the cost of improved services and much-needed investments in water infrastructure. Moreover, the new principles for water allocation have affected access to water for the water users in the catchment in unexpected ways. The Nyanyadzi waterscape is quite unique in the country, with the oldest right to water belonging to a smallholder irrigation scheme rather than White settler farmers, and with land transferred to the indigenous African population before the fast-tracking of the land reform process. Disconnecting water from land by abolishing the riparian rights principle, just when the native African population finally had the legal opportunity to own land, and replacing it with an expensive and cumbersome permit system, negatively affected the access of smallholder farmers to water resources (see also Manzungu and Machiridza, 2009; Van Koppen et al., 2014). Moreover, the abolishment of water entitlements based on priority date has triggered a physical transformation of the Nyanyadzi waterscape. Downstream water users have abandoned their hydraulic property and left their land in the irrigation scheme to move further upstream, to farm in closer proximity of the river where entitlements are less secure and where sophisticated infrastructure is absent, but where access to water is cheaper and more reliable. The policy makers involved in crafting the Zimbabwean water reform process did not intend to reduce the water use of lawful permit holders and surely did not envisage the increase of water use by illegal abstractors, yet this is the outcome of the reforms implemented in Nyanyadzi catchment during a politically and economically tumultuous period. This outcome is not neutral, but highly political, since locally influential actors have considerably increased their access to and control over land and water resources in the catchment. Further, the unforeseen outcome of the water reform process is used by both the ruling as well as the opposition party in their rivalry campaigns to gain legitimacy.
We therefore conclude that, beyond examining the content of the water law itself, and given the complex and dynamic socio-nature processes in waterscapes, more attention should be given to understanding what happens to, and with, water that escapes stipulated plans, prescribed rules of control and visible decision-making arenas. Remotely-sensed images, and more importantly, the critical and interdisciplinary analysis of these, may help to track processes of change and can enrich rigorous assessment of policy outcomes. Such analyses should be combined with qualitative methods for groundtruthing, which would help to provide empirically validated interpretations of observed changes in NDVI (or other) values. This might be a more sensible approach for steering reform processes within dynamic contexts than relying on a set of fixed indicators such as number of permits granted, number and value of fees collected and number of meetings held, as these say little about the actual distribution and use of water within a catchment.

\section{ACKNOWLEDGMENTS}

The work presented in this paper was funded by Directoraatgeneraal Internationale Samenwerking (DGIS), UNESCOIHE and the Geneva Water Hub. We thank the anonymous reviewers of the journal for their constructive comments on earlier versions of this article. We are greatly saddened by the sudden passing of our friend and co-author Ndaka Chinguno, our thoughts are with her husband, children, relatives and friends.

\section{REFERENCES}

AHLERS R, CLEAVER F, RUSCA M and SCHWARTZ K (2011) Informal space in the urban waterscape: disaggregation and co-production of water services. Water Altern. 7 (1) 154-167.

ANDERSSON JA (1999) The politics of land scarcity: land disputes in Save communal area, Zimbabwe. J. South. Afr. Stud. 25 (4) 553-578. https://doi.org/10.1080/030570799108470

ANDERSSON JA (2007) How much did property rights matter? Understanding food insecurity in Zimbabwe: a critique of Richardson. Afr. Affairs 106 (425) 681-690. https://doi.org/10.1093/ afraf/adm064

BABBIE E and MOUTON J (1998) The Practice of Social Research (South African Edition). Oxford University Press Southern Africa Limited, Cape Town.

BOLDING A (2004) In hot water: a study on socio-technical intervention models and practices of water use in smallholder agriculture, Nyanyadzi catchment, Zimbabwe. PhD thesis, Wageningen University.

CLEAVER F and ELSON D (1995) Women and water resources: continued marginalisation and new policies. The Gatekeeper Series of International Institute for Environment and Development's Sustainable Agriculture Programme 49 3-16.

CHIKOZHO C and LATHAM J (2005) Shona customary practices in the context of water sector reforms in Zimbabwe. Paper presented at: International workshop on African Water Laws: Plural Legislative Frameworks for Rural Water Management in Africa, January 2005, Johannesburg, South Africa.

CHINGUNO NLT (2012) From paper to practice: an analysis of the impact of the water reforms on the water use practices in Nyanyadzi River catchment, Zimbabwe. MSc thesis, UNESCO-IHE.

DI BALDASSARRE G, KOOY M, KEMERINK JS and BRANDIMARTE L (2013) Towards understanding the dynamic behaviour of floodplains as human-water systems. Hydrol. Earth Syst. Sci. Discuss. 10 3869-3895. https://doi.org/10.5194/ hessd-10-3869-2013 
GOZ (Government of Zimbabwe) (1998a) Water Act. Government Printers, Harare.

GOZ (Government of Zimbabwe) (1998b) Zimbabwe National Water Authority Act. Government Printers, Harare.

JASPERS FGW (2001) The new water legislation of Zimbabwe and South Africa: Comparison of legal and institutional reform. Int. Environ. Agreem. Polit. Law Econ. $1305-325$. https://doi. org/10.1023/A:1011524107299

KEMERINK JS (2015) Policies lost in translation? Unravelling water reform processes in African waterscapes. $\mathrm{PhD}$ thesis, Delft University of Technology. Taylor and Francis, Leiden.

KEMERINK JS, AHLERS R and VAN DER ZAAG P (2011) Contested water right in post-apartheid South-Africa: The struggle for water at catchment level. Water SA 37 (4) 585-594. https://doi. org/10.4314/wsa.v37i4.16

KEMERINK JS, MÉNDEZ BARRIENTOS LE, AHLERS R, WESTER $P$ and VAN DER ZAAG P (2013) Challenging the concept of Water User Associations as the vehicle for transformation: The question of inclusion and representation in rural South Africa. Water Polic. 15 (2) 243-257. https://doi.org/10.2166/wp.2012.127

KIRGER N (2005) ZANU(PF) strategies in general elections, 19802000: Discourse and coercion. Afr. Affairs 104 (414) 1-34. https:// doi.org/10.1093/afraf/adi016

KOMAKECH H, VAN KOPPEN B, MAHOO H and VAN DER ZAAG P (2011) Pangani River Basin over time and space: On the interface of local and basin level responses. Agric. Water Manage. 98 (11) 1740-1751. https://doi.org/10.1016/j.agwat.2010.06.011

KUJINGA K (2002) Decentralizing water management: An analysis of stakeholder participation in the management of water in Odzi subcatchment area, Save Catchment. Phys. Chem. Earth 27 897-905. https://doi.org/10.1016/S1474-7065(02)00092-X

KUJINGA K and MANZUNGU E (2004) Enduring contestations: Stakeholder strategic action in water resource management in the Save Catchment Area, Eastern Zimbabwe. E. Afr. Soc. Sci. Res. Rev. 20 (1) 67-91.

LOWNDES V (2005) Something old, something new, something borrowed... Polic. Stud. 26 (3-4) 291-309. https://doi. org/10.1080/01442870500198361

MAGADLELA D (1999) Whose water right: A look at irrigators and catchment farmers' water relations in Nyamaropa. In: Manzungu E, Senzanje A and Van der Zaag P (eds) Water for Agriculture in Zimbabwe: Policy and Management Options for the Smallholder Sector. University of Zimbabwe Publications, Harare. 29-45.

MAKURIRA H and MUGUMO H (2003) Water sector reforms in Zimbabwe: the importance of policy and institutional coordination on implementation. Chapter 14. Proc. African Regional Workshop on Watershed Management, October 2003, Nairobi.

MANZUNGO E and KUJINGA K (2002) The theory and practice of governance of water resources in Zimbabwe. Zambezia XXIX (ii).
MANZUNGU E and MACHIRIDZA R (2009) Economic-legal ideology and water management in Zimbabwe: implications for smallholder agriculture. Econ. Manage. Fin. Markets 4 (1) 66-102.

MANZUNGU E (2012) The shifting sands of natural resource management in Zimbabwe. Special issue on Natural Resources and Sustainable Development. J. Soc. Dev. Afr. 27 7-21.

MEEHAN KM (2014) Tool-power: Water infrastructure as wellsprings of state power. Geoforum 57 215-224. https://doi.org/10.1016/j. geoforum.2013.08.005

OSCC (Odzi Sub-Catchment Council) (2010) Minutes of the Annual General Meeting held on 17 December 2010. Odzi Sub-Catchment Council, Mutare, Zimbabwe.

SITHOLE M and MAKUMBE J (1997) Elections in Zimbabwe: The ZANU (PF) hegemony and its incipient decline. Afr. J. Polit. Sci. 2 (1) 122-139.

SVUBVURE O, AHLERS R and VAN DER ZAAG P (2011) Representational participation of informal and formal smallholder irrigation in the Zimbabwe water sector: A mirage in the Mzingwane catchment. Afr. J. Agric. Res. 6 (12) 2843-2855.

SWATUK LA (2008) A political economy of water in southern Africa. Water Alternatives 1 (1) 24

SWYNGEDOUW E (1999) Modernity and hybridity: Nature, regeneracionismo, and the production of the Spanish waterscape, 1890-1930. Ann. Assoc. Am. Geogr. 89 443-465. https://doi. org/10.1111/0004-5608.00157

VAN DER ZAAG P and BOLDING A (2009) Water governance in the Pungwe River Basin: institutional limits to the upscaling of hydraulic infrastructure. In: Swatuk LA and Wirkus L (eds.) Transboundary Water Governance in Southern Africa: Examining Unexplored Dimensions. Nomos, Baden-Baden. 163-177. https:// doi.org/10.5771/9783845212890-163

VAN KOPPEN B, VAN DER ZAAG P, MANZUNGU E and TAPELA B (2014) Roman water law in rural Africa: the unfinished business of colonial dispossession. Water Int. 39 (1) 49-62. https://doi.org/10.1 080/02508060.2013.863636

WESTER P, MERREY DJ and DE LANGE M (2003) Boundaries of consent: stakeholder representation in river basin management in Mexico and South Africa. World Dev. 31 (5) 797-812. https://doi. org/10.1016/S0305-750X(03)00017-2

ZAWE C (2006) Reforms in turbulent times: a study of the theory and practice of three irrigation management policy reform models in Mashonaland, Zimbabwe. PhD thesis, Wageningen University.

ZIKHALI P (2010) Fast track land reform programme, tenure security and investments in soil conservation: Micro-evidence from Mazowe District in Zimbabwe. Nat. Resour. Forum 34 (2) 124-139. https://doi.org/10.1111/j.1477-8947.2010.01298.x

ZIMMERER KS and BASSETT TJ (2003) Political Ecology: An Integrated Approach to Geography and Environment-Development Studies. The Guilford Press, New York. 